\title{
Role of Wood Flour on Physical and Mechanical Properties in Polymer Matrix Composites- A Critical Review
}

\author{
Lalit Ranakoti ${ }^{1}$, Pawan Kumar Rakesh ${ }^{1}$, Brijesh Gangil ${ }^{*}$ \\ ${ }^{1}$ Department of Mechanical Engineering, NIT, Uttarakhand 246174, India \\ ${ }^{2}$ Department of Mechanical Engineering, H.N.B. Garhwal University, Srinagar Garhwal 246174, India
}

Corresponding Author Email: brijesh.gangil@hngbu.ac.in

https://doi.org/10.18280/rcma.310203

Received: 9 July 2020

Accepted: 11 December 2020

\author{
Keywords: \\ polymer composites, wood flour, nanoparticle
}

\begin{abstract}
Green and sustainable material is the utmost prerequisite for the advancement of a healthy society and fulfilling the necessary for the improvement in material science. Naturally obtaining wood flour has the competence to be reinforced as a filler substance in the polymer composite. The present article deals with the usage of wood flour as a filler in the polymer composite. The article comprises properties, characteristics, occurrence, the structure of wood, and the techniques implemented in the manufacturing of wood flour polymer composites. In addition, critical parameters and causes that can bring changes in the properties like tensile, flexural, impact and hardness of polymers are also discussed with the addition of wood flour alone and with nanoparticles. The advantages of using wood flour as a filler in the thermoset and thermoplastic polymers discussed, and its hybridization with various natural fibers was also discussed in the present study.
\end{abstract}

\section{INTRODUCTION}

Every composite fabricated in the society of research possess a uniqueness for which it is acclaimed and appreciated [1]. Synthetic and natural fiber composites can be manufactured for various purposes in various combination with or without fillers. These purposes can be strength base, tribological base, environment base, economic base or any other purpose that can contribute to the improvement of the society. The contribution made by any research can be small or big but opens a variety of options for the upcoming generation to decide or understand the present situation of the domain [2]. The composite material was introduced around 4000 BC, long time ago and till now thousands of papers/articles have been reported and implemented in the real world of composite material for the confirmation of the feasibility of the results. In this respect, relative to metals and ceramics, many have reported that they have produced polymer composites that perform well in many applications, but not in all areas. Taking this as a challenge to fill the dearth remains in the field of composite material, several improvements have been made in the development of composite material. These changes may be fiber type (natural or synthetic), fiber shape, fiber size (short fiber or long fiber), filler addition or polymer used (natural or synthetic). Researchers have used various natural fibres/fillers with different manufacturing technique like hand lay-up, compression molding, injecting molding, etc. To obtain optimum wear, low cost, and low density per unit volume with adequate specific strength [3]. Wood flour (WF) is a novel filler, naturally available in large amount and widely used for the development of polymer composite. It is also cheap, easily available, easy to process and highly compatible with most of the polymers. Polymer composite based on wood flour is generally praised for its low cost, renewability and comparable strength. It also possesses high thermal stability as compared to natural fiber composite due to presence of high percentage of lignin in the wood. The future of wood flour composite greatly depends on the composites manufactured in the past. The results presented in the past literature would be very much helpful in the understanding of the crucial aspect such as filler loading, fabrication technique, filler percentage, etc., while manufacturing upcoming wood flour composites. Bring forth all these aspects the present investigation discusses the dimensionality of WF in the field of composite structure which have been manufactured and being manufactured till date with or without the reinforcement of natural and synthetic fiber.

\subsection{Wood flour}

Wood is naturally abundant around the globe. It is found nearly everywhere on Earth, but the percentage varies concerning the area, as illustrated in Figure 1 [4]. Commonwealth of independent states (CIS) has the largest share of softwood of $50 \%$. It is because softwoods mainly contain woods which are found in the evergreen forest, for example pine, Bruce and balsa. These evergreen forests mostly found in countries like Estonia, Lithuania, Armenia, Ukraine, Romania etc. North America is the second-largest countries in terms of softwood followed by Europe and Asia. Hardwood is the wood mostly found in the region of temperate and tropical forests which is generally found in countries of South America followed by Asia and North America. Most commonly hardwood found in these regions is Oak, Maple, Birch etc. Its wideness witnesses its characteristics that have made wood in several categories in which many are still unknown to mankind 
[5]. Some commonly known types of wood are listed in Table 1 and Table 2, along with their mechanical and physical properties [6]. Majorly, wood can be classified into two groups as softwood or hardwood. Softwoods are also known as gymnosperm, which is used in the manufacturing of window, door, building construction, etc., example includes cedar, fir,
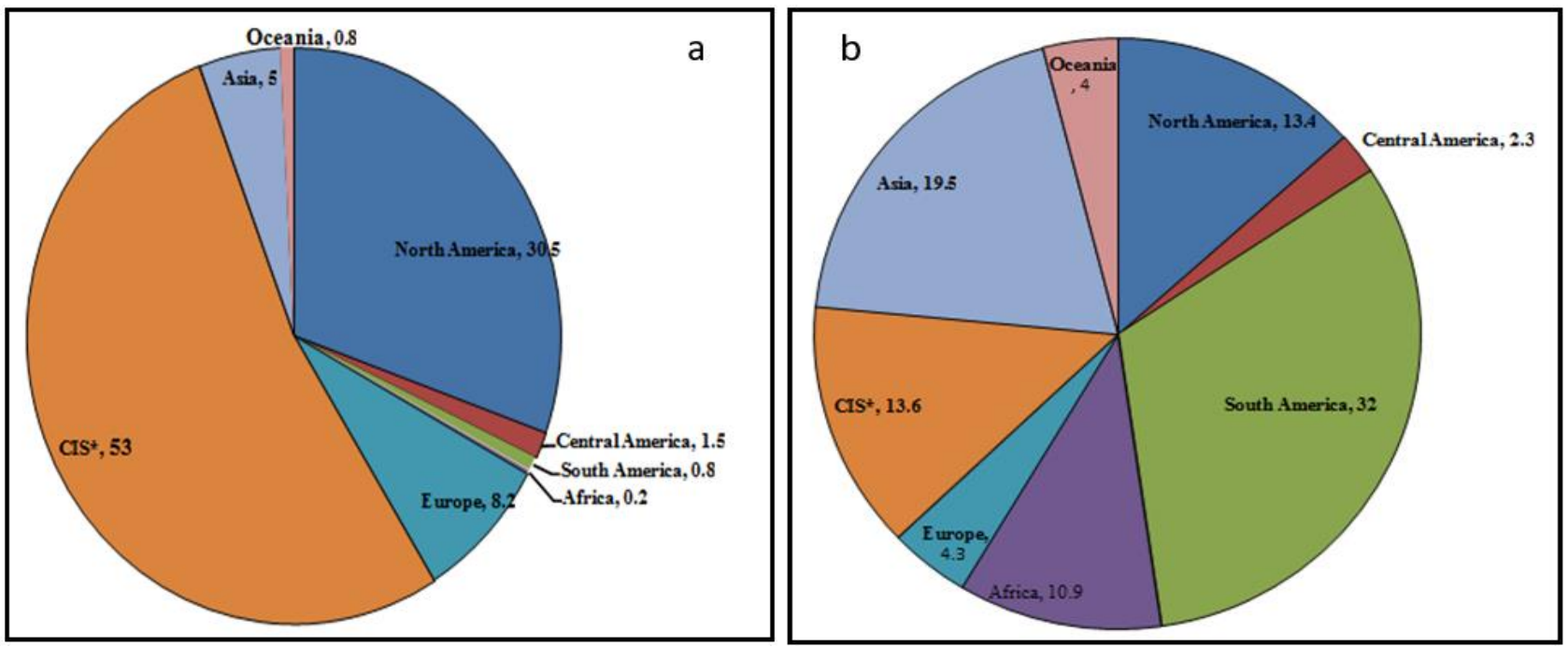

pines, spruce, and larch. On the other hand, Hardwoods are distinguished by the broadness of their leaves and found where the climate conditions are more deciduous and also known as angiosperm, example includes maple, oak, cherry, teak, etc. Generally, hardwoods are used in the manufacturing of massive constructions like the bridge, parts of dams, etc.

Figure 1. Percentage of wood flour naturally found around the world (a) Softwood (b) Hardwood

Table 1. Properties of softwood

\begin{tabular}{|c|c|c|c|c|c|c|}
\hline Species & $\begin{array}{l}\text { Modulus of } \\
\text { elasticity(psi) }\end{array}$ & $\begin{array}{c}\text { Shear } \\
\text { strength(psi) }\end{array}$ & $\begin{array}{l}\text { Compress } \\
\text { ion } \\
\text { parallel } \\
\text { to grain } \\
\text { (psi) } \\
\end{array}$ & $\begin{array}{c}\text { Compression perpendicular to } \\
\text { the grain(psi) }\end{array}$ & $\begin{array}{c}\text { Modulus } \\
\text { of } \\
\text { rupture( } \\
\text { psi) }\end{array}$ & $\begin{array}{l}\text { Specific } \\
\text { gravity }\end{array}$ \\
\hline Pine, red & 1281 & 686 & 2730 & 259 & 820 & 0.42 \\
\hline Fir, grand & 1250 & 739 & 2939 & 475 & 5839 & 0.35 \\
\hline $\begin{array}{l}\text { Spruce, } \\
\text { Engelmann }\end{array}$ & 1029 & 637 & 2180 & 197 & 705 & 0.33 \\
\hline Redwood & 1177 & 803 & 4210 & 424 & 500 & 0.39 \\
\hline Fir, white & 1161 & 756 & 2902 & 491 & 5854 & 0.37 \\
\hline $\begin{array}{l}\text { Douglas fir, } \\
\text { coast type }\end{array}$ & 1560 & 904 & 3784 & 700 & 7665 & 0.45 \\
\hline Larch, western & 1458 & 869 & 3756 & 676 & 7652 & 0.48 \\
\hline Pine, sugar & 1032 & 718 & 2459 & 214 & 893 & 0.34 \\
\hline Pine, longleaf & 1586 & 1041 & 4321 & 804 & 8538 & 0.54 \\
\hline Pine, lodgepole & 1076 & 685 & 2610 & 252 & 490 & 0.39 \\
\hline $\begin{array}{l}\text { Cedar, eastern } \\
\text { red }\end{array}$ & 649 & 1008 & 3570 & 700 & 30 & 0.46 \\
\hline Fir, balsam & 1251 & 662 & 2631 & 187 & 517 & 0.32 \\
\hline Pine, ponderosa & 997 & 704 & 2450 & 282 & 130 & 0.39 \\
\hline Fir, noble & 1380 & 802 & 3013 & 478 & 6169 & 0.37 \\
\hline $\begin{array}{l}\text { Cedar, western } \\
\text { red }\end{array}$ & 939 & 771 & 2774 & 244 & 184 & 0.31 \\
\hline $\begin{array}{l}\text { Pine, western } \\
\text { white }\end{array}$ & 1193 & 677 & 2434 & 192 & 688 & 0.35 \\
\hline Pine, shortleaf & 1388 & 905 & 3527 & 573 & 7435 & 0.47 \\
\hline Spruce, black & 1382 & 739 & 2836 & 242 & 118 & 0.38 \\
\hline Pine, loblolly & 1402 & 863 & 3511 & 661 & 7300 & 0.47 \\
\hline Spruce, Sitka & 1230 & 757 & 2670 & 279 & 660 & 0.38 \\
\hline Fir, Pacific silver & 1420 & 746 & 3142 & 414 & 6410 & 0.39 \\
\hline $\begin{array}{l}\text { Hemlock, } \\
\text { western }\end{array}$ & 1307 & 864 & 3364 & 457 & 6637 & 0.42 \\
\hline $\begin{array}{c}\text { Hemlock, } \\
\text { eastern }\end{array}$ & 1073 & 848 & 3080 & 359 & 420 & 0.39 \\
\hline
\end{tabular}

Waste obtained after the cutting of wood is globally termed as wood flour (WF). These wastes WF are generally used in filling between the cardboard or making of cardboard when combined with gum-like resin, and if the available is enormous, 
then it is used as roofs and decks where a large number of woods are cut [7]. These limited applications of WF have led to piling up of the large amount of WF in the Earth crust, which is not a severe problem for the environment point of view since WF is biodegradable natural dust, but much space required for the disposal of WF [8]. The problem of space cannot be resolved entirely but can be reduced to some extent. This can be made possible by using WF in composite material which can contribute to the mechanical and tribological properties of the final composite [9]. WF, which is generally found in pulverized form, has size vary from fine powder to grain of wheat. Cutting of wood does not produce the uniform size of WF. Hence aspect ratio generally deviates from 1-5 (length to diameter ratio). Metering and facilitation during the processing of WF hence become simple due to these low aspect ratios when compared with wood fiber.

Table 2. Properties of hardwood

\begin{tabular}{|c|c|c|c|c|c|c|}
\hline Species & $\begin{array}{c}\text { Modulus of } \\
\text { elasticity(psi) }\end{array}$ & $\begin{array}{l}\text { Compressi } \\
\text { on } \\
\text { perpendicu } \\
\text { lar to the } \\
\text { grain (psi) } \\
\end{array}$ & $\begin{array}{c}\text { Compression parallel to } \\
\text { grain (psi) }\end{array}$ & $\begin{array}{c}\text { Shear } \\
\text { strength(psi) }\end{array}$ & $\begin{array}{l}\text { Modulus } \\
\text { of } \\
\text { rupture(p } \\
\text { si) }\end{array}$ & $\begin{array}{l}\text { Specific } \\
\text { gravity }\end{array}$ \\
\hline Yellow-poplar & 1222 & 269 & 2660 & 792 & 950 & 0.4 \\
\hline Ash, white & 1436 & 667 & 3990 & 1354 & 500 & 0.54 \\
\hline Sweetgum & 1201 & 367 & 3040 & 991 & 110 & 0.46 \\
\hline $\begin{array}{l}\text { Beech, } \\
\text { American }\end{array}$ & 1381 & 544 & 3550 & 1288 & 570 & 0.57 \\
\hline Oak, white & 1246 & 671 & 3560 & 1249 & 300 & 0.6 \\
\hline $\begin{array}{l}\text { Cottonwood, } \\
\text { eastern }\end{array}$ & 1013 & 196 & 2280 & 682 & 260 & 0.37 \\
\hline $\begin{array}{l}\text { Oak, northern } \\
\text { red }\end{array}$ & 1353 & 614 & 3440 & 1214 & 300 & 0.56 \\
\hline $\begin{array}{l}\text { Sycamore, } \\
\text { American }\end{array}$ & 1065 & 365 & 2920 & 996 & 470 & 0.46 \\
\hline Maple, silver & 943 & 369 & 2490 & 1053 & 820 & 0.44 \\
\hline Tupelo, black & 1031 & 485 & 3040 & 1098 & 40 & 0.47 \\
\hline Hackberry & 954 & 399 & 2650 & 1070 & 480 & 0.49 \\
\hline Alder, red & 1167 & 250 & 2960 & 770 & 540 & 0.38 \\
\hline $\begin{array}{l}\text { Basswood, } \\
\text { American }\end{array}$ & 1038 & 170 & 2220 & 599 & 960 & 0.32 \\
\hline Birch, paper & 1170 & 273 & 2360 & 836 & 380 & 0.48 \\
\hline Elm, American & 1114 & 355 & 2910 & 1002 & 190 & 0.46 \\
\hline Maple, sugar & 1546 & 645 & 4020 & 1465 & 480 & 0.57 \\
\hline $\begin{array}{l}\text { Oak, southern } \\
\text { red }\end{array}$ & 1141 & 547 & 3030 & 934 & 920 & 0.53 \\
\hline
\end{tabular}

\subsection{Characteristics of wood flour}

Wood comprises mainly cellulose, lignin, and hemicellulose. Ash and extractives are also found in wood but very meagre quantity. It is approximately $70 \%$ cellulose, $20 \%$ lignin, $5 \%$ extractives, and $0.25 \%$ ash, as shown in Figure 2. These compositions are not fixed but vary from species to species [10].

Being the highly abundant, cellulose is considered the most important and main structural element of wood. Cellulose has a linear structure that comprises carbon, oxygen, and hydrogen. These three elements are arranged in units of $\beta$-D- glucose to form long and linear chains. Cellulose has a molecular weight ranging from 5000-2500000, which depends on the genesis of the sample. Most of the proportion of cellulose is crystalline, which is clutch together by the intermolecular hydrogen bonding. Reactivity of cellulose depends upon the hydroxyl groups which are present not only between the cellulose and hydroxyl group and but also between the cellulose and water groups. Cellulose is polar due to which it is easily attracted to water and forms hydrogen bonding. The degree of reactivity with water depends upon the number of free hydroxyl groups and clearly describes the penetration of water which is not found in crystalline sites but takes the amorphous sites. This water penetration causes swelling in wood but can be limited by chain movement [11]. Structure of hemicellulose is similar to cellulose but relatively short in chains due to which it gets degraded easily. However, frequent polymerization takes place, which is tens or hundreds of repeating units.

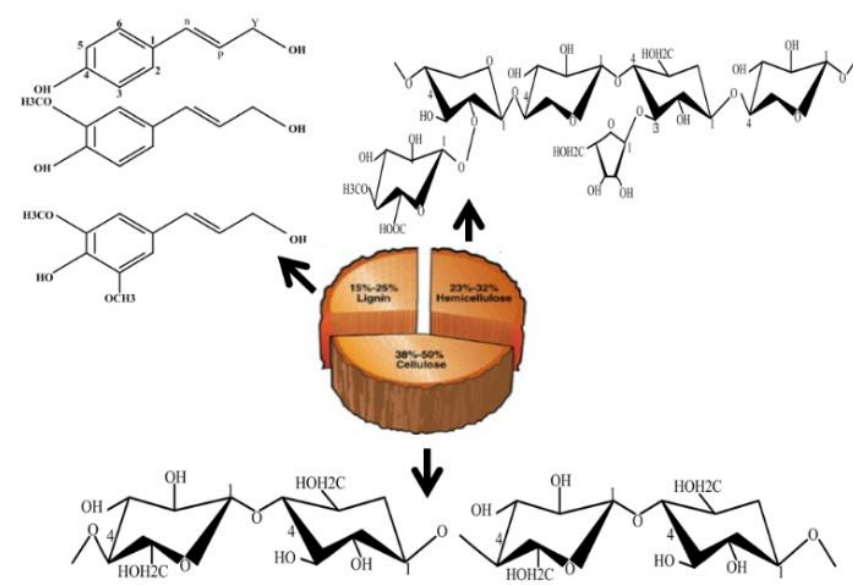

Figure 2. Chemical composition of wood

Fibers of cellulose are held together by lignin. Lignin is brittle which bound and provides stiffness to fibers. Lignin is thought to be a wall of inert material which allows the transfer of stress from the fiber to the matrix. Lignin is generally found more in softwood than in hardwood. It is about $30-35 \%$ in softwood and $20-25 \%$ in hardwood. Lignin composed of 
phenolic material which is combined in several ways and comes up with a three dimensional highly branched structure thus forming an isotropic substance [12]. Structure of lignin consists of stable benzene ring having 6 members of carbon atoms. Moreover, the occurrence of hydroxyl atoms found to be very low, making it less reactive than cellulose.

Extractives present in woods are organic elements which are generally extracted from the wood surface using some kind of solvents. Waxes, tannins, oils, carbohydrates, fats, gums, resins, and acids are some of the known extractives which are found in wood. Extractives play their part in the properties like permeability, durability and hygroscopic. Extractives do not form a strong bond with the wood surfaces and therefore can be easily removed. Extractives, found in wood can be classified into three groups [13]. These are aliphatic compounds, phenolic and terpenes compounds. Aliphatic contains waxes, fatty alcohols, esters, and fatty acids. Resin and turpentine are the compounds that belong to the category of terpenes while lignans, stilbenes, flavonoids, and tropolones are the compounds belong to the phenolic compounds. From the literature survey, it comes to know that many processes have identified to remove these extractives such as ether extraction, steam distillation, water extraction and alcohol extraction. Terpenes and fatty alcohols are extracted by steam distillation and ether extraction, respectively. Some extractives are water and alcohol soluble and can be easily removed though. These are tannins, carbohydrates and inorganic compounds.

\subsection{Structure of wood}

Structure of wood can be classified as ring formation, which takes place year by year. The formation of the ring starts from the inner core to the outermost layer. As these rings are exposed to a different environment for a different period, hence possess different structural, chemical and physical properties. The formation of several rings and its properties vary from species to species. Rings of wood are broadly classified in earlywood and latewood. Earlywood is those inner parts of the wood which grow during the early stage of the plant. Outer rings which formed at later period of the growing season are called latewood [14]. Early woods have less interaction with the environment and least affected by the variation of season hence remain soft, weak and light in weight than latewood. Every cell of wood is unique based on their structure and alignment elongated, ends with pointed edges and have oriented with the axis of the stem. Dissimilarity in the size of the cells can be seen for the earlywood or latewood. As thin walls with large cavities are found in earlywood while vice versa for latewood. Wood structure composed of cells that are concentrically arranged and differ in chemical characteristics and orientation [15]. Figure 3 shows different layers of cell wall, which are stick together by a substance called middle lamella (ML). ML is free of cellulose and has a property of gluing two phases.

Layers shown in Figure 3 are recognized by the orientation of cellulosic fiber present in the wall. Layers present in the cell of wood are called by their name, as shown in Figure 2. These are $\mathrm{P}, \mathrm{S} 1, \mathrm{~S} 2$, and $\mathrm{S} 3 . \mathrm{P}$ is primary wall and $\mathrm{S} 1, \mathrm{~S} 2, \mathrm{~S} 3$ are called secondary wall 1, 2 and 3 respectively. Arrangement of fibers in these walls is different to one another for example in $\mathrm{P}$ wall crossing of cellulosic fibers can be seen while in $\mathrm{S} 1$, and S2 fibers arranged in slight slope and roughly aligned for the direction of fiber respectively [16]. Percentage of cellulose in P and S3 found to be less than the other two layers, but the S3 layer has a large amount of substance which is nonstructural. Substance, which bound the cavity in the cell wall, is known as lumen. Earlywood and latewood have different wall thicknesses which depend on the thickness of layer S2. S2 is the layer where the majority of cellulose is present, having an average density of about $1.49 \mathrm{~g} / \mathrm{cm}^{3}$. Almost $90 \%$ of the volume of wood contains cells of softwood aligned in the axial direction called tracheids. On the other hand, cells of hardwood consist of fibers, vessels and parenchyma cells. On an average length of softwood varies from 1 to $10 \mathrm{~mm}$ while, length of hardwood fibers limit to $1.2 \mathrm{~mm} \mathrm{[17].} \mathrm{The} \mathrm{higher}$ amount of cellulose provides strength to the wood while lignin contributes in maintaining the thermal stability, while high number of aliphatic groups works as a binding agent. These features of wood enable us to implement the wood as a filler or fiber in the polymer composites, which can serve a future composite material with a touch of renewability.

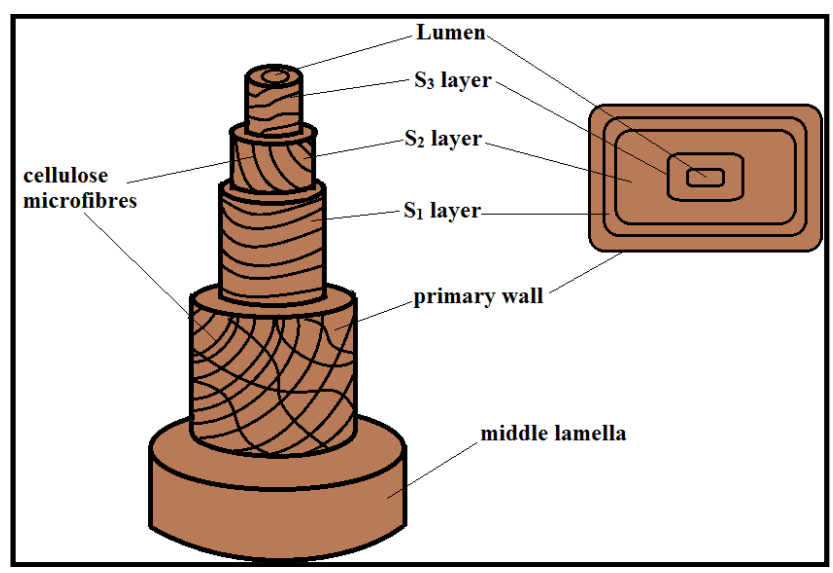

Figure 3. Structure of wood

\section{MANUFACTURING OF WOOD FLOUR COMPOSITE}

Primarily, wood flour polymer composites are manufactured by using techniques such as injection molding, extrusion, thermoforming or compression molding. While, Laser sintering and fused layer modeling are some new manufacturing processes which include additives.

\subsection{Injection moulding}

Parts having complex geometries and require no finishing are generally manufactured by Injection molding. In injection molding process wood flour can be blended with the variety of polymers like polypropylene, polystyrene, and polyethylene. In addition to the polymers, fibers like flax, palm waste, and rice husk can also be added to the blend. In this process wood flour or fiber is mixed with the polymer is maintained at a certain temperature. The mixture is then poured in the die and pressure is applied through the ram so that the material can take the required shape. Using wood flour in injection molding leads to high energy savings; this is because of the flow of wood flour-polymer takes place at relatively low temperature and pressure. The temperature during processing kept between $180^{\circ}$ to $200^{\circ}$ centigrade. Products manufactured by injection molding possess uniformity in color and dispersion [18]. Special attention is required when the mixture is filled in the 
die due to its shear sensitivity. Post cap of guard rail structure is the most common application. Molecular foams of wood flour composite are also being targeted to be manufactured by injection molding.

\subsection{Extrusion process}

The extrusion process manufactures a large number of wood flour composites. The purpose of the extruder, which is the most important part of the extrusion process, is used in the mixing of wood, polymer, and additives if any. This mixing is called compounding. This mix is then transferred to the die for further processing. Four types of extrusion process are known for the manufacturing of wood flour polymer composite. These are:

(1) Single screw, (2) co-rotating twin-screw, (3) counterrotating twin-screw and (4) Woodtruder.

A single screw is simplest among all. It consists of a barrel having a 34:1 ratio of length to diameter. The process is carried out in two steps i.e., melting and metering. There is one vent section which is used to exhaust volatile matters. The material used in the single screw is in the form of pellet filled with fiber. These pellets are dried with the help of drier. Feeding of material is carried out by gravity. Mechanism of screw shear and the heating barrel is used for mixing and melting respectively [19]. Capital investment is low for a single screw which is one such advantage, but high material cost and lower output rates make this technique least prefer for the manufacturer. Moreover, higher risk of the decomposition rate of fiber and maintaining of adequate temperature are some issues which make this technique least suitable.

Wood-plastic composites can also be easily manufactured by coupling parallel co-rotating twin-screw extruder having $\mathrm{L} / \mathrm{D}$ ratio of $40: 1$ with holt melt single screw extruder (L/D: 10:1). Wood flour/fiber with raw polymer or additives can be easily used without pre-blending. The gravimetric feeder is used for the feeder mechanism. Additional screw speed is added to barrel heat and screw mixing for melting and mixing process. Both atmospheric and vacuum vents are used for the removal of moisture. The extruder is accompanied with inbuilt drier and blending. Thus, pre-drying and proper mixing can be achieved with additional operations [20]. High screw speed, absent of screw cooling, complex venting mechanism and need of a peripheral system for feeding are some disadvantages for co-rotating twin-screw extruder.

Polymer like polyvinyl chloride (PVC) which is highly heated sensitive, fibers or foam which are processed at low extrusion temperature, blends of powder also known as noncompounded material, materials in which feeding is very much tricky and those which require degassing are generally processed with counter-rotating twin screw extrusion. Both conical and parallel screw configuration can be used in counter-rotating twin-screw extrusion. Fibers are first dried before mixing them with the polymer and additives usually of size 250 to $400 \mu \mathrm{m}$. Crammer feeder is used for feeding mechanism. Melting and mixing mechanism is same as in single screw extruder. Vacuum venting is used for the removal of moisture. Low shear in mixing, low screw speed, and its proven technology are some advantages of counter-rotating twin screw extrusion [21]. On the other hand, the use of drier, mechanism of size reduction during feeding, the requirement of the pre-blending system are the additional necessities of the system.

Woodtruder is another manufacturing technique used for making wood-plastic composites. It consists of counterrotating twin of L/D ratio of 28:1 with $75 \mathrm{~mm}$ single screw extruder. It also includes a blender control system, sprays cooling tank, blending unit, travelling cut off saw and a table for runoff. During the processing, wood flour/fiber with some initial moisture content is kept in the feeder and is dried with the help of twin-screw. In the meantime, the plastic is under preparation to melt. The melting of the polymer ensures no burning of fiber. The mechanism of melting and mixing is the same as in the case of a single screw extruder. The mixing of material then carried out, and moisture is removed by vacuum venting. Pre material preparation is not required in this system, and feeding mechanism is carried out by Gravimetric feeder. Execution of process at the ambient moisture content ( 5 to $8 \%$ ), independent processing of wood fiber and polymer, efficient mixing of fiber and polymer, adequate cooling rate, excellent venting mechanism, high flexibility are some advantages of this system. While disadvantages include higher initial set up cost, lower product throughput, etc. [22].

\section{WOOD FLOUR COMPOSITES}

WF is reinforced with varieties of products which are generally processed at a temperature lower than $200^{\circ} \mathrm{C}$ for example amendments in soil, absorbents for explosive, glues extenders, etc. Initially, WF was used as filler with phenolformaldehyde but, later polymer like polyamides, polyesters, polypropylene, polyethylene, and polystyrene have experimented with WF for the fabrication of composite [23]. Products of high strength in WF composites are generally not achieved because of its low thermal stability and its hydrophilic nature but to enhance the mechanical properties and adhesiveness of WF based composites, various Compatibilizers and coupling agents have been used. Maleic anhydride-modified polypropylene (MAPP) is the most common compatibilizer that has been used with WF composite and showed improvement in the strength of WF polymer composite. Silane, Zirconate, and titanate are some coupling agents which, when treated to WF improves the adhesive property, and sometimes water is used in place of coupling agents to provide compactness to WF. The content of moisture can define the adhesive property of WF it retains as more moisture affects the final mechanical property of WF composite. Moreover, the shape and size of the WF also play a very critical role in deciding the mechanical property of the WF composite.

Research and development in the field of WF polymer composite are now considered at a higher level by various academicians. An approach of making compatible the WF with various polymers is now taking place at every level of composite technology. These approaches are manufacturing process, polymer matrix, percentage of WF, types of WF, shape, and size of WF, treatment of WF and so on. Availability of WF and its low cost also the reason of greater attention towards WF polymer composites.

\subsection{Mechanical properties of wood flour plastics}

Composite of wood pulp and light density polyethylene (LDPE) was manufactured and investigated for mechanical properties. In addition, poly (ethyleneco-glycidyl methacrylate) was used as compatibilizers [24]. Results show that the addition of compatibilizers achieves higher tensile and impact strength. 
Tensile and flexural strength of various WF polymer composites treated with coupling agents is shown in Figure 4 and Figure 5, respectively. It can be observed that MAPP and silane are commonly applied coupling agents and providing a satisfactory result. It can be illustrated from the figures that silane treated WF-PLA composite gives the highest tensile strength, and MAPP treated WF-PP composite gives the highest flexural strength.

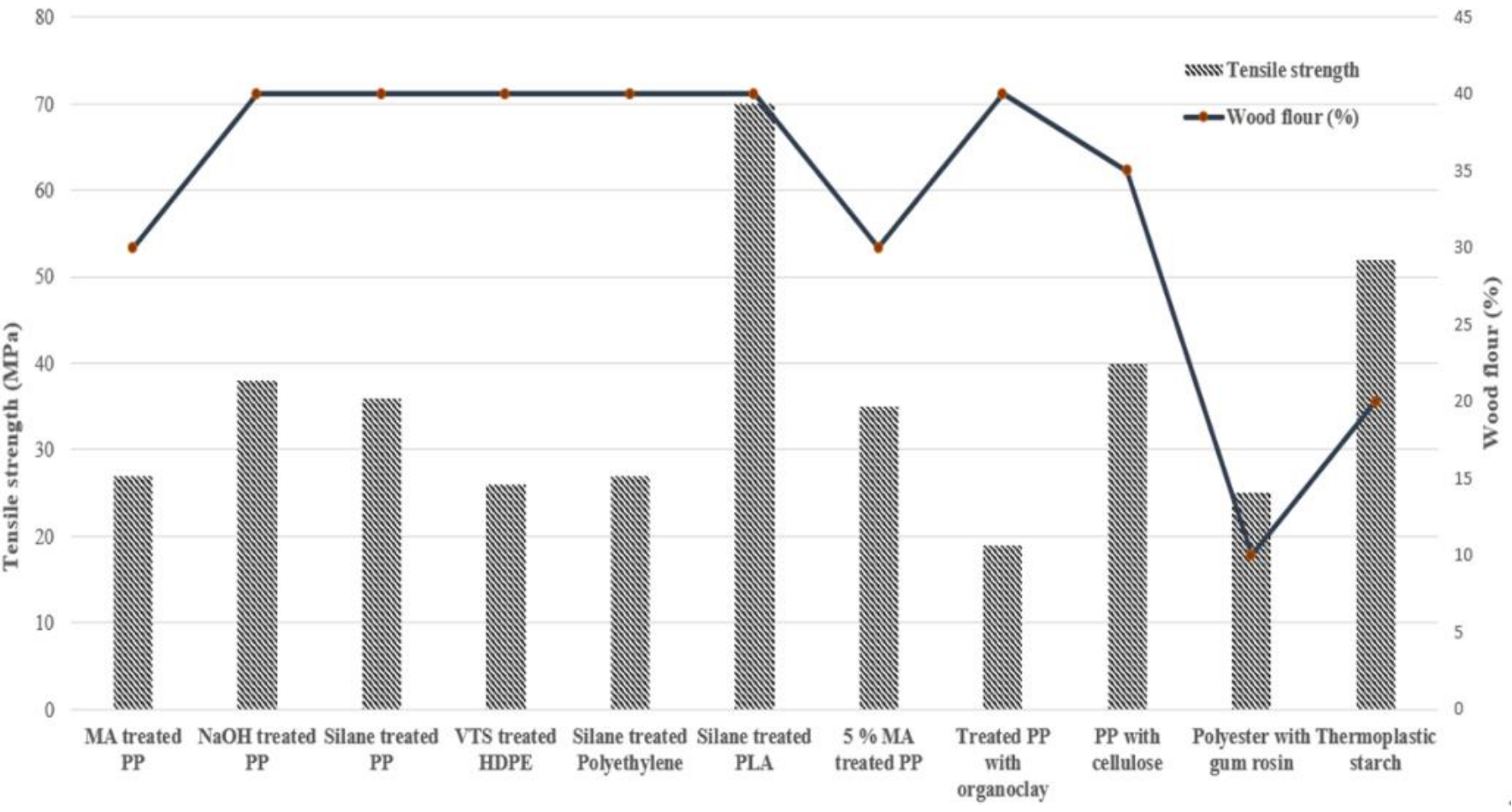

Figure 4. Tensile strength of polymer composites at varying WF\% [25-34]

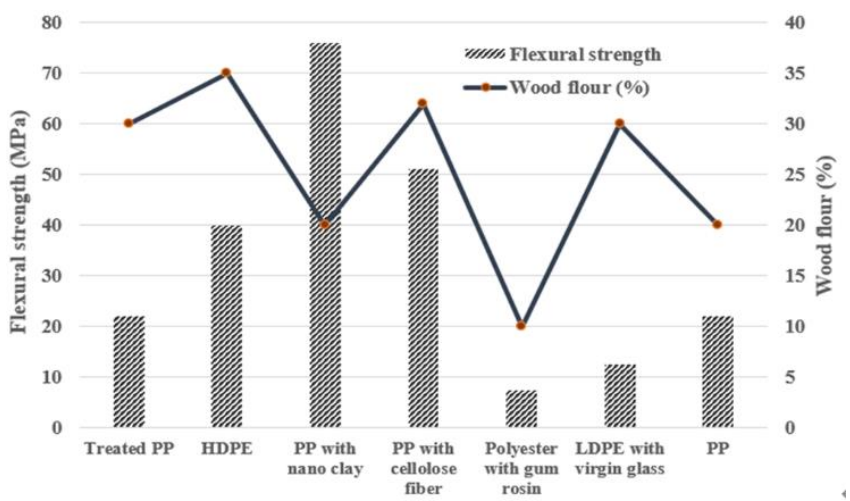

Figure 5. Flexural strength of polymer composites at varying WF\% [35-39]

Several composites of WF were also manufactured with the high-density polyethylene (HDPE). Blends of ionomer and HDPE with wood flour filler was investigated for weathering and mechanical properties.

It was demonstrated that the addition of pigments and ultraviolet absorber improves the resistance of composites against degradation. Similar composition with the WF filler percentage of $60 \%$ was reported for the toughness and strength. It was stated that immiscibility of ionomer and polymer plays an important role in load transfer efficiency of the composite. Residue made up of agro-waste are sometimes beneficial to use as filler material in place of WF. Composite made up of wheat straw-HDPE polymer exhibit higher mechanical properties when compared with WF-HDPE composite. Water absorption capability of WF-HDPE composite has always remained an issue which can be sort by the addition of compatibilizers. In this regard, WF filled HDPE composite treated with Maleic Anhydride polypropylene (MAPP), silane and alkaline resulted in higher flexural, impact and greater resistance to moisture absorption [40]. One of the most common and durable polymers that exist in the market is polypropylene (PP). Several composites have been analyzed and investigated for WF filled polypropylene composite. For instance, WF-polypropylene composite at $60 \%$ wt. Percentage of WF exhibit superior impact strength. Results reported in the study are dependent on the fiber length and the physical property of the wood.

Enhancement in the creep modulus is observed with the addition of MAPP. MAPP has come in various form with different molecular weight, but it is suggested that MAPP having the higher molecular weight and lower functionality is a better coupling agent for the composite with higher strength. Apart from MAPP, m-isopropenyl- $\alpha, \alpha$-dimethylbenzylisocyanate is one such coupling agent who brings improved mechanical properties in the WF-PP composite [41]. The problem of high moisture absorption is always associated with the WF composite, which generally resulted in poor mechanical strength. Moisture absorption of WF composites can be reduced by using coupling agents or by changing the manufacturing techniques i.e., injection molding with high screw rotation. Various experiments have been carried out with WF-polyvinyl chloride (PVC) composites. WF-PVC composites modified with silane coupling agent exhibit good tensile and impact strength as compared to untreated composites. Impact strength of various polymer with WF is illustrated in Table 3. Effect of various compatibilizer, fire retardant and lubricant are reported in Table 3. For instance, cross-linking of PP results in $209.5 \mathrm{~J} / \mathrm{m}$ of impact strength at 70 wt. \% WF while HDPE based WF composite show impact 
strength of $80 \mathrm{~J} / \mathrm{m}$ at $40 \mathrm{wt} . \% \mathrm{WF}$. PP based composite gives much lesser impact strength than HDPE, PVC and polyester at almost equal content of WF. The reason may be the property of plastic as it belongs to the thermoset plastic, which is not as strong as thermoplastic. Meanwhile, the impact strength of various polymers based WF composite with varying degree of WF content treated or untreated can be seen in Table 3. Table 3 also conveys that treatment of WF along with chopped carbon fiber leads to maximum impact strength.

Further, including organo-modified montmorillonite (OMMT) in the composite leads to enhanced fire retardancy of the composites. Advancement in the mechanical property of the composite is accredited to the improvement in the adhesion between the filler and the matrix [42]. Composite made up of waste PVC, and WF was investigated for cyclic loading in extrusion milling cycles. Improvement in the flexural properties is observed, but no change noticed in other mechanical properties at 20 cycles. Further, the decline in the degradation temperature and improvement in the impact strength is observed at 20 cycles for the composite [43]. WF in the PVC matrix does not bring any change in the surface tension and flexibility with the change in the percentage of WF in the composition; however, the formation of smoke and heat quantity is significantly affected. Moreover, char formation increases appreciably in the composite with the addition of WF in the PVC matrix. It will be worth saying that loading percentage, particle size, and concentration of filler have their significance in the deciding mechanical properties of the composite. WF-polystyrene composite with the filler percentage of $30 \%$ having the mesh size of 60 grafted with silane and isocyanates coupling agents exhibit superior mechanical properties as compared to untreated composite. Sometimes it becomes mandatory to fabricate a lighter weight composite which solely depends on the density of the final composite. WF filled Expanded polystyrene grafted with maleic anhydride can be manufactured with low density and comparable mechanical strength [44]. Inclusion of fiber in the WF-polystyrene composite is also a beneficial move for the composite to fabricate. The incorporation of glass fiber observes better flexural strength and hardness to the composite.

Table 3. Impact strength of WF-polymer composites [45-55]

\begin{tabular}{|c|c|c|c|c|c|}
\hline $\begin{array}{c}\text { S. } \\
\text { No. }\end{array}$ & $\begin{array}{l}\text { Matrix } \\
(\text { Wt. \%) }\end{array}$ & $\begin{array}{l}\text { Wood flour } \\
\text { (Wt. \%) }\end{array}$ & $\begin{array}{l}\text { Impact } \\
\text { strength }\end{array}$ & Comment & Application \\
\hline 1 & XLPE $(68 \%)$ & 30 & $209.5 \mathrm{~J} / \mathrm{m}$ & $\begin{array}{l}\text { Polymer was cross linked with WF via silane } \\
\text { technology }\end{array}$ & Window lining \\
\hline 2 & HDPE $(70 \%)$ & 30 & $10.5 \mathrm{KJ} / \mathrm{m}^{2}$ & $\begin{array}{l}\text { Polymer was cross linked with WF via silane } \\
\text { technology along with } 4 \% \text { fire retardant }\end{array}$ & $\begin{array}{l}\text { High strength } \\
\text { cardboards used in } \\
\text { marine }\end{array}$ \\
\hline 3 & $\mathrm{PP}(58 \%)$ & 40 & $46 \mathrm{~J} / \mathrm{m}$ & PP was treated with 2 wt. $\%$ of Maleaic Anhydride & Doors and decking \\
\hline 4 & $\mathrm{PP}(58 \%)$ & 40 & $36 \mathrm{~J} / \mathrm{m}$ & $\begin{array}{l}\text { PP was treated with } 2 \text { wt. } \% \text { of Maleaic Anhydride } \\
\text { along with treatment of WF by } 1 \% \text { zinc borate }\end{array}$ & Doors and decking \\
\hline 5 & HDPE $(55 \%)$ & 35 & $4.2 \mathrm{KJ} / \mathrm{m}^{2}$ & $5 \%$ mineral particles were added in the composite & Boards and lumber \\
\hline 6 & $\mathrm{PP}(44 \%)$ & 47 & $5.57 \mathrm{~J} / \mathrm{m}$ & $\begin{array}{c}3 \text { wt. } \% \text { malaeic anhydride, } 4 \% \text { fire retardant and } 2 \% \\
\text { lubricant were added in the composite }\end{array}$ & $\begin{array}{l}\text { Parts for marine } \\
\text { engineering }\end{array}$ \\
\hline 7 & HDPE $(40 \%)$ & 60 & $80 \mathrm{~J} / \mathrm{m}$ & $\begin{array}{l}\text { Sodium ionomer was added @ } 40 \% \text { of the total } \\
\text { volume of composite }\end{array}$ & Boards and lumber \\
\hline 8 & PPC $(80 \%)$ & 20 & $14.2 \mathrm{KJ} / \mathrm{m}^{2}$ & PPC was grafted with maleaic anhydride & Frames and trims \\
\hline 9 & Polyester $(75 \%)$ & 10 & $13 \mathrm{~J}$ & $\begin{array}{c}15 \% \text { gum rosin was used to enhanced the interfacial } \\
\text { bonding }\end{array}$ & Building materials \\
\hline 10 & HDPE $(40 \%)$ & 58 & $59 \mathrm{~J} / \mathrm{m}$ & $\begin{array}{l}2 \text { wt. \% MAPE was used and effect of WF geometry } \\
\text { of mesh size } 20 \text { was analyzed }\end{array}$ & Automotive industries \\
\hline 11 & HDPE $(40 \%)$ & 58 & $63 \mathrm{~J} / \mathrm{m}$ & $\begin{array}{c}2 \text { wt. \% MAPE was used and effect of WF geometry } \\
\text { of mesh size } 60 \text { was analyzed }\end{array}$ & Automotive industries \\
\hline 12 & $\mathrm{PP}(40 \%)$ & 30 & $\begin{array}{l}6.25 \mathrm{KJ} / \mathrm{m}^{2} \text { (un } \\
\text { notched) } \\
1.5 \mathrm{KJ} / \mathrm{m}^{2} \\
\text { notched }\end{array}$ & Fire retardant @30\% was used in the study & Furnishing materials \\
\hline 13 & $\operatorname{PVC}(70 \%)$ & 30 & $26.5 \mathrm{KJ} / \mathrm{m}^{2}$ & WF was treated with $2 \%$ lignin amine & packaging \\
\hline 14 & $\operatorname{PVC}(70 \%)$ & 30 & $26 \mathrm{KJ} / \mathrm{m}^{2}$ & Wood flour was treated with $1 \%$ lignin amine & packaging \\
\hline 15 & $\operatorname{HDPE}(70 \%)$ & 30 & $1.12 \mathrm{KJ} / \mathrm{m}^{2}$ & Fire retardant was used @ 4\% & \\
\hline 16 & $\begin{array}{l}\text { Recycled PP } \\
\quad(39 \%)\end{array}$ & 50 & $3.45 \mathrm{KJ} / \mathrm{m}^{2}$ & WF was treated with 9 wt. $\%$ of ethylene acetate & $\begin{array}{l}\text { Equipment's for } \\
\text { showcase }\end{array}$ \\
\hline 17 & $\mathrm{PP}(70 \%)$ & 25 & $26.5 \mathrm{~J} / \mathrm{m}$ & $\begin{array}{l}\text { Significant improvement of about } 39.4 \% \text { was } \\
\text { observed with the addition of 5\% MAPP }\end{array}$ & Doors and panels \\
\hline 18 & PP $(52 \%)$ & 40 & $20 \mathrm{~J} / \mathrm{m}$ & $\begin{array}{c}\text { Treated with 5\% MAPP along with the addition of } \\
3 \% \text { organ clay }\end{array}$ & Doors and panels \\
\hline 19 & $\begin{array}{l}\text { Recycled } \\
\text { Polystyrene } \\
(50 \%)\end{array}$ & 50 & $5.2 \mathrm{~J} / \mathrm{m}$ & $\begin{array}{l}23.8 \% \text { increase was observed in impact strength due } \\
\text { to recycling of Polystyrene }\end{array}$ & $\begin{array}{l}\text { Equipment for } \\
\text { showcase }\end{array}$ \\
\hline 20 & PP $(22 \%)$ & 63 & $3.3 \mathrm{KJ} / \mathrm{m}^{2}$ & $\begin{array}{c}3 \% \text { MAPP, } 2 \% \text { lubricant was used along with } 10 \\
\text { wt. \% of chopped carbon fiber leads to reduction in } \\
19.51 \% \text { in impact strength }\end{array}$ & Chairs and tables \\
\hline 21 & PP $(22 \%)$ & 63 & $3.8 \mathrm{KJ} / \mathrm{m}^{2}$ & $\begin{array}{l}3 \% \text { MAPP, } 2 \% \text { lubricant was used along with } 10 \\
\text { wt. \% of fiber leads to reduction in } 7.31 \% \text { in impact } \\
\text { strength }\end{array}$ & Chairs and tables \\
\hline
\end{tabular}




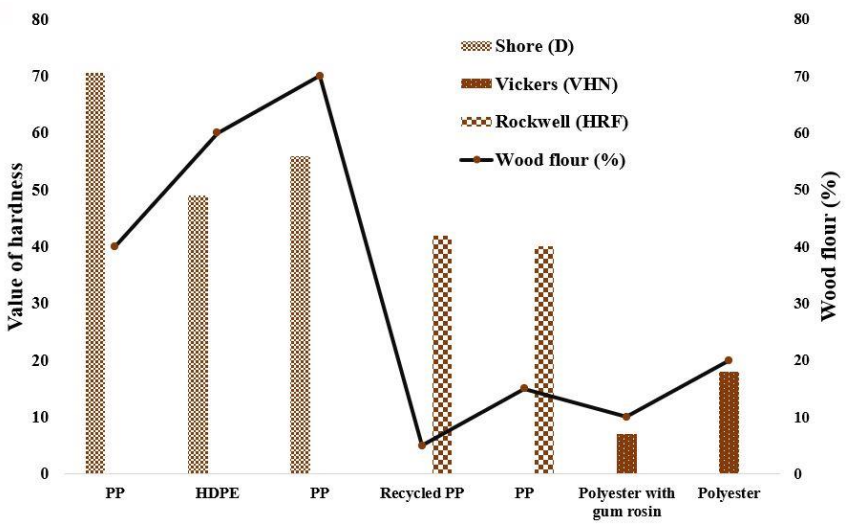

Figure 6. Hardness of composite with varying percentage of WF with PP, HDPE and Polyester [56-58]

The hardness of PP, HPPE and Polyester with various percentage of WF has been shown in Figure 6. Shore hardness, Rockwell hardness and Vickers hardness are shown in Figure 6. Inclusion of wood flour in the polymer matrix enhances the hardness due to the increase in the rigidity and surface texture. Being light in density wood flour settles mostly at the surface of the composite which brings the changes in the surface properties of the composite, especially hardness. Shore hardness of the PP based wood flour composite was found to be maximum at $40-50 \%$ WF content that shows the more aggregation of the wood flour at the surface than at the core while it decreases as the wood flour content increases beyond $60 \mathrm{wt} . \%$ that must be attributed to the inability of polymer to saturate wood flour in it thus leads to a decrease in shore hardness. Figure 6 also shows that Shore hardness of HDPE based WF composite is almost equivalent to the PP based WF composite. Increasing WF content in the polyester lead to increases in the Rockwell hardness number, but the Vickers hardness number decreases as the WF content increase in the PP. The hardness of the wood flour-based composite generally depends on the filler content and size. It has been best hardness is usually obtained at $35 \mathrm{wt} . \%$ of filler content and a further increase in the filler content in the polymer matrix may lead to a reduction in the value of hardness. On the whole, it can be summarized that the maximum impact of WF is observed for shore hardness among all the hardness because of the amount of WF and maybe testing parameters, as shown in Figure 6.

\subsection{Mechanical properties of wood flour polymer nanocomposite}

The literature has shown that the WF filled polymer composite typically exhibits comparatively low mechanical characteristics. The explanation for this is the weak adhesion of the WF to the matrix. In addition, earlier studies have shown that wood as a fibre has a higher tensile and flexural strength than wooden flour in the polymer matrix. To increase the mechanical strength of WF polymer composite, the introduction of nanofillers is very much a beneficial move in the history of WF-polymer composites. Thoroughly dispersed nanofillers have higher surface area; thus, act as a medium for a better stress transfer between the filler and the matrix. To analyze the inter chemistry of the structure due to the addition of nano-filler in the WF polymer composite various testing techniques are available such as X-Ray diffraction (XRD), scanning electron micrographs (SEM), Transmission electron microscope (TEM), etc. In this regard, several nanoparticles have been implemented for the manufacturing of WF polymer nanocomposite. Higher mechanical properties, together with higher thermal stability, can be acquired by introducing nanoparticles of silica in the WF-LDPE composite [59]. The problem of dispersion of silica nanoparticles can be eliminated by the use of dicumyl peroxide (DCP). DCP also enhances the interaction between WF and matrix in the composite. Most commonly known nanofiller organic- montmorillonite (OMMT) enhanced the tensile and impact strength of the WF polymer composite by the amount of $9.7 \%$ and $15.4 \%$ respectively [60]. TEM results suggested that improvement in the strength may be attributed to the effective dispersion of OMMT into the matrix. Increasing the OMMT \% to $3 \%$ leads to the agglomeration of nanofiller, which in turn reduces the impact strength. A similar observation can be seen in the case of the nano-filler of clay. Improper distribution of nano-fillers into the WF polymer composite results in a reduction in mechanical strength but the use of coupling agents can improve the dispersion of nano-filler, thus enhancement of interfacial adhesion. Better impact strength, tensile strength, and toughness can also be achieved by the incorporation of organically modified cloister nano clay to the WF-PE composite. Findings reported in the investigation indicated that cloister shed off easily in the matrix due to opposite polarities and higher clay density, resulting in increased interfacial adhesion but not much improvement observed in the moduli of the composite. In the presence of MAPP nano clay has other phenomena to discuss. Increasing the percentage of nano clay to $20 \%$ in the WF -PP composite result in a reduction in impact strength and tensile strength. Probably the reason for the reduction may be increased viscosity and restriction in the movement of a chain of the matrix, but loading nano clay in WF-PP composite beyond $20 \%$ enhanced the tensile strength and toughness slightly [61]. Sometimes it is observed that nano clay put detrimental effects on WF polymer composites in regards to fracture energy and strain at break. This lowering of property is attributed to the weakening in interfacial bonding beyond the clay loading of $10 \%$. Moreover, nanoparticles of clay promote the stress concentration, which further encourages the crack formation [62].

Nanoparticles have a significant effect on hybrid composites. It has been found that clay percentage of 1 to $5 \%$ in hemp-PP composite result in improved tensile strength and elongation at break but compromising the impact strength [63]. Similar observations can be seen in the case of the bagasse-PP composite as clay improves the tensile modulus and yield of composite with the increment of $26 \%$ and $15 \%$ respectively. Use of different types of nanoparticles such as $\mathrm{TiO}_{2}, \mathrm{SiO}_{2}$, $\mathrm{ZnO}_{2}$, clay, etc. together in WF-polymer composite also produces greater tensile strength and flexural strength as compared to the WF-polymer composite without nanoparticles [64]. It should be noted that the weight content of nanoparticles should not exceed beyond 5\%. Organically modified nano clay particles have also been investigated with WF-LDPE composites. Increase in Young's modulus was observed with the enhancement in the WF- matrix adhesion. Further, including the 5 wt. \% MAPP in the WF-HDPE composite result in improvement in flexural strength of the composite [65]. Pristine form of nano clay in the WF-PP composite also increases the flexural and tensile strength significantly. Carbon nanotubes (CNT) and micro cellulose are some other nanoparticles which have incorporated in WFpolymer composites in a substantial number of studies to 
achieve higher mechanical strength. CNT in WF-PVC composites with the addition of 5 wt. \% CNT increases flexural modulus and flexural strength. Single wall carbon nanotubes (SWCNT) can be applied in WF-LDPE composites to obtain better mechanical properties [66]. It should be noted that the percentage of SWCNT is kept below $3 \mathrm{wt}$. \%. In the case of Nanofibers of carbon (CNF), a composite made of WFPP- MAPP does not exhibit any substantial change in strength. Poor dispersion and low interfacial adhesion of CNF in the composite is less or more be the reason and may be attributed to the hydrophobicity of the CNF. Higher-strength can also be achieved by the incorporation of microcrystal cellulose (MCC) in the WF-polymer composite [67]. Loading up to 5 wt. \% MCC in the WF-PP composite led to enhancement in tensile, flexural and impact strength.

\section{APPLICATIONS AND FUTURE SCOPE OF WF POLYMER COMPOSITE}

Wood is now being recognized as a commercial commodity in different types of applications such as constructions, furniture, automotive and consumer products etc. In the current scenario, WF polymer composites are also gaining popularity in applications like window, decking, door lineal, railing, fencing, tables, playground types of equipment, roofing etc. WF polymer composites are also playing a bigger part in the construction of interior parts of automotive sectors. However, the applications of wood flour polymer composites largely depend on the polymer matrix, size of wood flour, manufacturing method and coupling agent [68]. For instance, profiles having uniform cross-sections are mostly extruded such as windows profile, decking and railing while products with the complex profile are manufactured by injection molding or compression molding process for example household products, furniture and products for decoration. Parts for the automotive industries are being manufactured by thermoforming. Product manufactured from WF-poly vinyl chloride composites having mesh size of 140 has shown good weatherability which can perform in extremely humid conditions. WF-PLA composites are showing prominence in the market due to the renewability and good mechanical properties. Window and door lineal, roofing, picnic tables and benches, fencing, landscape timbers, patios, gazebos, pergolas, auto parts, and playground types of equipment are also being manufactured from wood flour polymer composites. Besides, structural components are being fabricated with WF-polymer composites. The expansion of WF in the field of the structure has been successfully accomplished by the addition of coupling agent like alkali solution in the WF-polymer composite [69] which decreased the affinity of WF towards moisture and improved the mechanical properties for a longer time.

Expansion of WF polymer composites can be achieved by continue research and developments that can help in penetration in the global markets. Injection moulding is the most preferred techniques for the manufacturing of toys and packaging. Fixing hooks, fan boxes, gloves boxes and sound system are some other applications of WF polymer composites that can be made by injection moulding.

Futuristic growth can be expected in WF polymer composites in the heavy structural applications. Research is under process for the enhancement of stiffness, strength and creep performance of WF polymer composites. WF can be cross-linked with PE in the presence of coupling agent like silane can increase toughness and durability. Structural properties can also be increased by the use of nanoparticles in the WF polymer composites. Solid metals are now being replaced by WF polymer composites that have applications like gazebos and pergolas [70].

\section{CONCLUSION}

Wood flour (WF) is an industrial waste forms during the processing of wood, and it is used as a natural filler for the manufacturing of filler-polymer composite. The ease of availability of WF, abundance and its low cost is an important reason for greater attention of the academicians towards WF polymer composites. Enhancement in the tensile strength can be achieved at 40 and $30 \mathrm{wt}$. \% WF for PLA and thermoplastic starch. Whereas, higher flexural strength can be achieved by the inclusion of nano clay in WF- PP composite. cross-linking of polymers dramatically helps in the improvement of impact strength. Addition of compatibilizers also plays a vital role in the enhancement of impact strength of the WF composites. An approach of making compatible the WF with various polymers is now taking place at every level of composite technology. These approaches are manufacturing process, polymer matrix, percentage of WF, types of WF, shape, and size of WF, treatment of WF and so on. The percentage of WF in the composite may be up to $60 \%$. The wood flour polymer composites are manufactured using techniques such as injection molding, extrusion, thermoforming or compression molding, Laser sintering and fused layer molding. To enhance the mechanical properties and adhesiveness of WF various Compatibilizers and coupling agents have been used. The pigments and ultraviolet absorber are also used to enhanced resistance of composites against degradation. It was reported that nanoparticles such as $\mathrm{TiO}_{2}, \mathrm{SiO}_{2}, \mathrm{ZnO}_{2}$, clay, etc. together in WF-polymer composite exhibited greater tensile strength and flexural strength as compared to the WF-polymer composite without nanoparticles.

\section{REFERENCES}

[1] Saheb, D.N., Jog, J.P. (1999). Natural fiber polymer composites: A review. Advances in Polymer Technology. Journal of the Polymer Processing Institute, 18(4): 351$363 . \quad$ https://doi.org/10.1002/(SICI)10982329(199924)18:4\%3C351::AID-ADV6\%3E3.0.CO;2$\mathrm{X}$

[2] Gao, W., Zhang, Y., Ramanujan, D., Ramani, K., Chen, Y., Williams, C.B., Zavattieri, P.D. (2015). The status, challenges, and future of additive manufacturing in engineering. Computer-Aided Design, 69: 65-89. https://doi.org/10.1016/j.cad.2015.04.001

[3] Lalit, R., Mayank, P., Ankur, K. (2018). Natural fibers and biopolymers characterization: A future potential composite material. Strojnícky časopis-Journal of Mechanical Engineering, 68(1): 33-50. https://doi.org/10.2478/scjme-2018-0004

[4] Lopes, R.M.C., Stofan, E.R., Peckyno, R., Radebaugh, J., Mitchell, K.L., Mitri, G., Wood, C.A., Kirk, R.L., Wall, S.D., Lunine, J.I., Hayes, A., Lorenz, R., Farr, T., Wye, L., Craig, J., Ollerenshaw, R.J., Janssen, M., LeGall, A., Paganelli, F., West, R., Stiles, B., Callahan, P., Anderson, 
Y., Valora, P., Soderblom, L., Hayes, A. (2010). Distribution and interplay of geologic processes on Titan from Cassini radar data. Icarus, 205(2): 540-558. https://doi.org/10.1016/j.icarus.2009.08.010

[5] Ranakoti, L., Gupta, M.K., Rakesh, P.K. (2019). Analysis of mechanical and tribological behavior of wood flour filled glass fiber reinforced epoxy composite. Materials Research Express, 6(8): 085327.

[6] Arao, Y., Nakamura, S., Tomita, Y., Takakuwa, K., Umemura, T., Tanaka, T. (2014). Improvement on fire retardancy of wood flour/polypropylene composites using various fire retardants. Polymer Degradation and Stability, 100 :

$79-85$ https://doi.org/10.1016/j.polymdegradstab.2013.12.022

[7] Ghani, W.A.W.A.K., Mohd, A., Desilva, G., Bachmann, R.T., Taufiq-Yap, Y.H., Rashid, U., Alaa, H. (2013). Biochar production from waste rubber-wood-sawdust and its potential use in $\mathrm{C}$ sequestration: chemical and physical characterization. Industrial Crops and Products, 44: 18-24. https://doi.org/10.1016/j.indcrop.2012.10.017

[8] Sommerhuber, P.F., Welling, J., Krause, A. (2015). Substitution potentials of recycled HDPE and wood particles from post-consumer packaging waste in WoodPlastic Composites. Waste Management, 46: 76-85. https://doi.org/10.1016/j.wasman.2015.09.011

[9] Ojha, S., Raghavendra, G., Acharya, S.K. (2014). A comparative investigation of bio waste filler (wood apple-coconut) reinforced polymer composites. Polymer Composites, 35(1):

https://doi.org/10.1002/pc.22648

180-185.

[10] Hamelinck, C.N., Hooijdonk, G.V., Faaij, A.P. (2005). Ethanol from lignocellulosic biomass: techno-economic performance in short, middle- and long-term. Biomass and Bioenergy, 28(4): 384-410. https://doi.org/10.1016/j.biombioe.2004.09.002

[11] Ranakoti, L., Gupta, M.K., Rakesh, P.K. (2019). Silk and silk-based composites: opportunities and challenges. In Processing of Green Composites, pp. 91-106. https://doi.org/10.1007/978-981-13-6019-0_7

[12] Azwa, Z.N., Yousif, B.F., Manalo, A.C., Karunasena, W. (2013). A review on the degradability of polymeric composites based on natural fibers. Materials \& Design, 47:

424-442. https://doi.org/10.1016/j.matdes.2012.11.025

[13] Duval, A., Lawoko, M. (2014). A review on lignin-based polymeric, micro-and nano-structured materials. Reactive and Functional Polymers, 85: 78-96. https://doi.org/10.1016/j.reactfunctpolym.2014.09.017

[14] Wiedenhoeft, A.C., Simeone, J., Smith, A., ParkerForney, M., Soares, R., Fishman, A. (2019). Fraud and misrepresentation in retail forest products exceeds US forensic wood science capacity. PloS One, 14(7): e0219917. https://doi.org/10.1371/journal.pone.0219917

[15] Labbe, N., Harper, D., Rials, T., Elder, T. (2006). Chemical structure of wood charcoal by infrared spectroscopy and multivariate analysis. Journal of agricultural and food chemistry, 54(10): 3492-3497. https://doi.org/10.1021/jf053062n

[16] Yang, J.S., Ni, J.R., Yuan, H. L., Wang, E. (2007). Biodegradation of three different wood chips by Pseudomonas sp. PKE117. International Biodeterioration \& Biodegradation, 60(2): 90-95. https://doi.org/10.1016/j.ibiod.2006.12.006

[17] Dwivedi, P., Alavalapati, J.R., Lal P. (2009). Cellulosic ethanol production in the United States: Conversion technologies, current production status, economics, and emerging developments. Energy for Sustainable Development, $13(3)$ : https://doi.org/10.1016/j.esd.2009.06.003

[18] Kuo, P.Y., Wang, S.Y., Chen, J.H., Hsueh, H.C., Tsai, M.J. (2009). Effects of material compositions on the mechanical properties of wood-plastic composites manufactured by injection molding. Materials \& Design, 30(9): https://doi.org/10.1016/j.matdes.2009.03.012

[19] Sykacek, E., Hrabalova, M., rech, H.F., Mundigler, N. (2009). Extrusion of five biopolymers reinforced with increasing wood flour concentration on a production machine, injection moulding and mechanical performance. Composites Part A: Applied Science and Manufacturing, 40(8): $1272-1282$. https://doi.org/10.1016/j.compositesa.2009.05.023

[20] Stark, N.M. (2006). Effect of weathering cycle and manufacturing method on performance of wood flour and high-density polyethylene composites. Journal of Applied Polymer Science, 100(4): 3131-3140.

[21] Wechsler, A., Hiziroglu, S. (2007). Some of the properties of wood-plastic composites. Building and Environment, $\quad 42(7)$ : 2637-2644. https://doi.org/10.1016/j.buildenv.2006.06.018

[22] Migneault, S., Koubaa, A., Erchiqui, F., Chaala, A., Englund, K., Wolcott, M.P. (2009). Effects of processing method and fiber size on the structure and properties of wood-plastic composites. Composites Part A: Applied Science and Manufacturing, 40(1): 80-85. https://doi.org/10.1016/j.compositesa.2008.10.004

[23] Lu, J.Z., Wu, Q., McNabb, H.S. (2007). Chemical coupling in wood fiber and polymer composites: a review of coupling agents and treatments. Wood and Fiber Science, 32(1): 88-104.

[24] Selke, S.E., Wichman, I. (2004). Wood fiber/polyolefin composites. Composites Part A: Applied Science and Manufacturing, 35(3): 321-326. https://doi.org/10.1016/j.compositesa.2003.09.010

[25] Nachtigall, S.M., Cerveira, G.S., Rosa, S.M. (2007). New polymeric-coupling agent for polypropylene/woodflour composites. Polymer Testing, 26(5): 619-628. https://doi.org/10.1016/j.polymertesting.2007.03.007

[26] Ichazo, M.N., Albano, C., Gonzalez, J., Perera, R., Candal, A.M. (2001). Polypropylene/wood flour composites: treatments and properties. Composite Structures, $\quad 54(2-3)$ : $207-214$ https://doi.org/10.1016/S0263-8223(01)00089-7

[27] Bengtsson, M., Gatenholm, P., Oksman, K. (2005). The effect of crosslinking on the properties of polyethylene/wood flour composites. Composites Science and Technology, 65(10): 1468-1479. https://doi.org/10.1016/j.compscitech.2004.12.050

[28] Lee, S.Y., Kang, I.A., Doh, G.H., Yoon, H.G., Park, B.D., $\mathrm{Wu}, \mathrm{Q}$. (2008). Thermal and mechanical properties of wood flour/talc-filled polylactic acid composites: Effect of filler content and coupling treatment. Journal of Thermoplastic Composite Materials, 21(3): 209-223. https://doi.org/10.1177\%2F0892705708089473

[29] Bakar, M.A., Ishak, Z.M., Taib, R.M., Rozman, H.D., Jani, S.M. (2010). Flammability and mechanical properties of wood flour-filled polypropylene composites. Journal of Applied Polymer Science, 116(5): 
2714-2722. https://doi.org/10.1002/app.31791

[30] Bouafif, H., Koubaa, A., Perre, P., Cloutier, A. (2009). Effects of fiber characteristics on the physical and mechanical properties of wood plastic composites. Composites Part A: Applied Science and Manufacturing, 40(12): $1975-1981$ https://doi.org/10.1016/j.compositesa.2009.06.003

[31] Khanjanzadeh, H., Tabarsa, T., Shakeri, A. (2012). Morphology, dimensional stability and mechanical properties of polypropylene-wood flour composites with and without nanoclay. Journal of Reinforced Plastics and Composites, 31(5): 341-350. https://doi.org/10.1177/0731684412438793

[32] Hemmasi, A.H., Eslam, H.K., Talaiepoor, M., Kord, B., Ghasemi, I. (2010). Effect of nanoclay on the mechanical and morphological properties of wood polymer nanocomposite. Journal of Reinforced Plastics and Composites, 29(7): 964-971. https://doi.org/10.1177\%2F0731684408101790

[33] Ndiaye, D., Tidjani, A. (2012). Effects of coupling agents on thermal behaviour and mechanical properties of wood flour/polypropylene composites. Journal of Composite Materials, 46(24): 3067-3075. https://doi.org/10.1177\%2F0021998311435675

[34] Nourbakhsh, A., Ashori, A., Tabari, H.Z., Rezaei, F. (2010). Mechanical and thermo-chemical properties of wood-flour/polypropylene blends. Polymer Bulletin, 65(7): 691-700. https://doi.org/10.1007/s00289-0100288-8

[35] Valente, M., Sarasini, F., Marra, F., Tirillo, J., Pulci, G. (2011). Hybrid recycled glass fiber/wood flour thermoplastic composites: Manufacturing and mechanical characterization. Composites Part A: Applied Science and Manufacturing, 42(6): 649-657. https://doi.org/10.1016/j.compositesa.2011.02.004

[36] Patel, V.K., Rawat, N. (2017). Physico-mechanical properties of sustainable Sagwan-teak wood flour/polyester composites with/without gum rosin. Sustainable materials and technologies, 13: 1-8. https://doi.org/10.1016/j.susmat.2017.05.002

[37] Christman, T., Needleman, A., Suresh, S. (1989). An experimental and numerical study of deformation in metal-ceramic composites. Acta Metallurgica, 37(11): 3029-3050. https://doi.org/10.1016/00016160(89)90339-8

[38] Kumar, S., Gangil, B., Patel, V.K. (2016). Physicomechanical and tribological properties of grewia optiva fiber/bio-particulates hybrid polymer composites. In AIP Conference Proceedings, 1728(1): 020384. https://doi.org/10.1063/1.4946435

[39] Scheibel, T., Parthasarathy, R., Sawicki, G., Lin, X.M., Jaeger, H., Lindquist, S.L. (2003). Conducting nanowires built by controlled self-assembly of amyloid fibers and selective metal deposition. Proceedings of the National Academy of Sciences, 100(8): 4527-4532. https://doi.org/10.1073/pnas.0431081100

[40] Cui, Y., Lee, S., Noruziaan, B., Cheung, M., Tao, J. (2008). Fabrication and interfacial modification of wood/recycled plastic composite materials. Composites Part A: Applied Science and Manufacturing, 39(4): 655661. https://doi.org/10.1016/j.compositesa.2007.10.017

[41] Karmarkar, A., Chauhan, S.S., Modak, J.M., Chanda, M. (2007). Mechanical properties of wood-fiber reinforced polypropylene composites: Effect of a novel compatibilizer with isocyanate functional group. Composites Part A: Applied Science and Manufacturing, $38(2)$ : 227-233. https://doi.org/10.1016/j.compositesa.2006.05.005

[42] Zhao, Y., Wang, K., Zhu, F., Xue, P., Jia, M. (2006). Properties of poly (vinyl chloride)/wood flour/montmorillonite composites: effects of coupling agents and layered silicate. Polymer Degradation and Stability, 91(12): 2874-2883. https://doi.org/10.1016/j.polymdegradstab.2006.09.001

[43] Augier, L., Sperone, G., Garcia, C.V., Borredon, M.E. (2007). Influence of the wood fibre filler on the internal recycling of poly (vinyl chloride)-based composites. Polymer Degradation and Stability, 92(7): 1169-1176. https://doi.org/10.1016/j.polymdegradstab.2007.04.010

[44] Ranakoti, L., Rakesh, P.K. (2020). Physio-mechanical characterization of tasar silk waste/jute fiber hybrid composite. Composites Communications, 22: 100526. https://doi.org/10.1016/j.coco.2020.100526

[45] Bengtsson, M., Oksman, K. (2006). The use of silane technology in crosslinking polyethylene/wood flour composites. Composites Part A: Applied Science and Manufacturing, 37(5): 752-765. https://doi.org/10.1016/j.compositesa.2005.06.014

[46] Badritala, A., Hashemi, S.K.H., Kord, B., Zabihzadeh, S.M., Safdari, V. (2013). Morphology and mechanical properties of zinc borate-pretreated poplar wood flour/plastic composite. BioResources, 8(1): 913-922.

[47] Chaudemanche, S., Perrot, A., Pimbert, S., Lecompte, T., Faure, F. (2018). Properties of an industrial extruded HDPE-WPC: the effect of the size distribution of wood flour particles. Construction and Building Materials, 162: 543-552.

https://doi.org/10.1016/j.conbuildmat.2017.12.061

[48] Khozeini, A., Tabarsa, T., Mashkour, M. (2014). A novel method for manufacturing of wood flour/PP composites with better fire retardancy and mechanical properties. International Journal of Lignocellulosic Products, 1(2): 121-133. https://doi.org/10.22069/IJLP.2014.2069

[49] Nornberg, B., Borchardt, E., Luinstra, G.A., Fromm, J. (2014). Wood plastic composites from poly (propylene carbonate) and poplar wood flour-Mechanical, thermal and morphological properties. European Polymer Journal, 51: 167-176. https://doi.org/10.1016/j.eurpolymj.2013.11.008

[50] Khonsari, A., Taghiyari, H.R., Karimi, A., Tajvidi, M. (2015). Study on the effects of wood flour geometry on physical and mechanical properties of wood-plastic composites. Maderas. Ciencia y tecnología, 17(3): 545558. 221X2015005000049 http://dx.doi.org/10.4067/S0718-

[51] Yue, X., Chen, F., Zhou, X. (2011). Improved interfacial bonding of PVC/wood-flour composites by lignin amine modification. BioResources, 6(2): 2022-2044.

[52] Pan, M., Mei, C., Song, Y. (2012). A novel fire retardant affects fire performance and mechanical properties of wood flour-high density polyethylene composites. BioResources, 7(2): 1760-1770.

[53] Ghahri, S., Najafi, S. K., Mohebby, B., Tajvidi, M. (2012). Impact strength improvement of wood flourrecycled polypropylene composites. Journal of Applied Polymer Science, 124(2): 1074-1080. https://doi.org/10.1002/app.34015

[54] Lisperguer, J., Bustos, X., Saravia, Y. (2011). Thermal 
and mechanical properties of wood flour-polystyrene blends from postconsumer plastic waste. Journal of Applied Polymer Science, 119(1): 443-451. https://doi.org/10.1002/app.32638

[55] Turku, I., Karki, T. (2014). The effect of carbon fibers, glass fibers and nanoclay on wood flour-polypropylene composite properties. European Journal of Wood and Wood $\quad$ Products, $72(1)$ : 73-79. https://doi.org/10.1007/s00107-013-0754-8

[56] Pandey, K.K. (1999). A study of chemical structure of soft and hardwood and wood polymers by FTIR spectroscopy. Journal of Applied Polymer Science, 71(12): 1969-1975. https://doi.org/10.1002/(SICI)10974628(19990321)71:12\%3C1969::AID-

APP6\%3E3.0.CO;2-D

[57] Stelte, W., Sanadi, A.R. (2009). Preparation and characterization of cellulose nanofibers from two commercial hardwood and softwood pulps. Industrial \& Engineering Chemistry Research, 48(24): 11211-11219. https://doi.org/10.1021/ie9011672

[58] Holm, J.K., Henriksen, U.B., Hustad, J.E., Sorensen, L.H. (2006). Toward an understanding of controlling parameters in softwood and hardwood pellets production. Energy \& Fuels, 20(6): 2686-2694. https://doi.org/10.1021/ef0503360

[59] Sailaja, R.R.N. (2006). Mechanical and thermal properties of bleached kraft pulp-LDPE composites: Effect of epoxy functionalized compatibilizer. Composites Science and Technology, 66(13): 2039-2048. https://doi.org/10.1016/j.compscitech.2006.01.029

[60] Tjong, S.C. (2006). Structural and mechanical properties of polymer nanocomposites. Materials Science and Engineering: R: Reports, 53(3-4): 73-197. https://doi.org/10.1016/j.mser.2006.06.001

[61] Deka, B.K., Maji, T.K. (2011). Effect of $\mathrm{TiO}_{2}$ and nanoclay on the properties of wood polymer nanocomposite. Composites Part A: Applied Science and Manufacturing, 42(12): 2117-2125. https://doi.org/10.1016/j.compositesa.2011.09.023

[62] Ashori, A., Nourbakhsh, A. (2011). Preparation and characterization of polypropylene/wood flour/nanoclay composites. European Journal of Wood and Wood Products, 69(4): 663-666. https://doi.org/10.1007/s00107-010-0488-9

[63] Kord, B., Kiakojouri, S.M.H. (2011). Effect of nanoclay dispersion on physical and mechanical properties of wood flour/polypropylene/glass fiber hybrid composites. BioResources, 6(2): 1741-1751.

[64] Nourbakhsh, A., Ashori, A. (2009). Influence of nanoclay and coupling agent on the physical and mechanical properties of polypropylene/bagasse nanocomposite. Journal of Applied Polymer Science, 112(3): 1386-1390. https://doi.org/10.1002/app.29499

[65] Yeh, S.K., Gupta, R.K. (2010). Nanoclay-reinforced, polypropylene-based wood-plastic composites. Polymer Engineering \& Science, 50(10): 2013-2020. https://doi.org/10.1002/pen.21729

[66] Tabari, H.Z., Nourbakhsh, A., Ashori, A. (2011). Effects of nanoclay and coupling agent on the physicomechanical, morphological, and thermal properties of wood flour/polypropylene composites. Polymer Engineering \& Science, 51(2): 272-277. https://doi.org/10.1002/pen.21823

[67] Faruk, O., Matuana, L.M. (2008). Reinforcement of rigid PVC/wood-flour composites with multi-walled carbon nanotubes. Journal of Vinyl and Additive Technology, 14(2): 60-64. https://doi.org/10.1002/vnl.20145

[68] Stark, N.M., Matuana, L.M., Clemons, C.M. (2004). Effect of processing method on surface and weathering characteristics of wood-flour/HDPE composites. Journal of Applied Polymer Science, 93(3): 1021-1030.

[69] Mantia, F.P.L., Morreale, M. (2011). Green composites: A brief review. Composites Part A: Applied Science and Manufacturing, 42(6): 579-588. https://doi.org/10.1016/j.compositesa.2011.01.017

[70] Limam, A., Zerizer, A., Quenard, D., Sallee, H., Chenak, A. (2016). Experimental thermal characterization of biobased materials (Aleppo Pine wood, cork and their composites) for building insulation. Energy and Buildings, 116: 89-95. https://doi.org/10.1016/j.enbuild.2016.01.007 